УДК (UDC): 911:504:314

DOI: https://doi.org/10.26565/1992-4259-2021-24-05

A. N. NEKOS ${ }^{1}$, DSc (Geographic), prof., Yu. I. MUROMTSEVA ${ }^{2}, \mathrm{PhD}$ (Economic), doc.

${ }^{l}$ V. N. Karazin Kharkiv National University

6 Svobody Sq., Kharkiv, 61022, Ukraine

${ }^{2}$ G.S. Scovoroda Kharkiv National Pedagogical University

29 Alchevskikh st., Kharkiv, 61002, Ukraine

e-mail:alnekos999@gmail.com

jmuromtseva@ukr.net

ORCID ID:https://orcid.org/0000-0003-1852-0234 https://orcid.org/0000-0003-2787-6080

\title{
ESTIMATION OF THE AIR EMISSIONS OF POLLUTANTS INFLUENCE ON PRIMARY MORBIDITY INDICATOR OF THE POPULATION : CASE IN KHARKIV REGION - UKRAINE
}

Purpose. To establish structural shifts in the indicators of the primary morbidity of the population, and to determine the relationship between the indicators of emissions of pollutants into the air and the primary morbidity of the population of the Kharkiv region.

Methods. We used system approach, statistical methods.

Results. The structure and dynamics of the number of newly registered cases of diseases and primary morbidity of the population were considered during the period from 2004 to 2017 . A correlation-regression analysis of the relationships between emissions and primary morbidity by disease classes in the Kharkiv region was made, which showed the presence of a moderate correlation between the phenomena. The synthesized regression equations can be used to determine the influence of each individual factor $\left(\mathrm{SO}_{2}, \mathrm{CO}_{2}, \mathrm{~N}_{2} \mathrm{O}\right.$ emissions) on the primary morbidity of the population for different classes of diseases. In the structure of primary morbidity of the population of Kharkiv region, the major share is made up of diseases of the respiratory, circulatory and nervous systems their share increased from $49 \%$ in 2004 to $51 \%$ in 2017 year.

Conclusions. The indicators of primary morbidity by diseases of the genitourinary system, nervous system, circulatory system and congenital malformations were the most sensitive to air pollutions and emission $\mathrm{CO}_{2}$ into the atmosphere. The most negative impact on the values of all classes of primary morbidity in the Kharkiv region have $\mathrm{CO}_{2}, \mathrm{~N}_{2} \mathrm{O}$.

KEY WORDS: environmental factors, primary morbidity, Kharkiv region, dynamics of morbidity, emissions, pollutants

НЕКОС А. Н. ${ }^{1}$, МУРОМЦЕВА Ю. I. $^{2}$ Україна;

${ }^{1}$ Харківський національний університет імені В. Н. Каразіна, майдан Свободи, 6, м. Харків, 61022,

${ }^{2}$ Харківський національний педагогічний університет імені Г.С. Сковороди, вул. Алчевських, 29, м. Харків, 61002 ,Україна;

ОЦНКА ВПЛИВУ ВИКИДІВ ЗАБРУДНЮЮЧИХ РЕЧОВИН У АТМОСФЕРУ НА ПОКАЗНИКИ ПЕРВИННОЇ ЗАХВОРЮВАНОСТІ НАСЕЛЕННЯ (НА ПРИКЛАДІ ХАРКІВСЬКОЇ ОБЛАСТІ)

Мета. Встановити структурні зміни у показниках первинної захворюваності населення, та визначити взаємозв'язок між показниками викидів забруднюючих речовин в атмосферне повітря та первинною захворюваністю населення Харківської області.

Методи. Системний підхід, статистичні методи.

Результати. Проаналізовано структуру й динаміку кількості вперше зареєстрованих випадків захворювань та первинної захворюваності населення за період з 2004 по 2017 рр. Здійснено кореляційнорегресійний аналіз зв'язків між обсягами викидів та первинною захворюваністю за класами хвороб у Харківській області, який показав наявність помітного зв'язку між явищами. Синтезовані рівняння регресії можна використовувати для визначення впливу кожного окремого фактора (викиду $\mathrm{SO}_{2}, \mathrm{CO}_{2}, \mathrm{~N}_{2} \mathrm{O}$ ) на

(C) Nekos A. N., Muromtseva Yu. I., 2021 
первинну захворюваність населення за різними класами хвороб. У структурі первинної захворюваності населення Харківської області значну частку займають хвороби органів дихання, системи кровообігу та нервової системи - їх питома вага збільшилася з 49\% в 2004 р. до $51 \%$ в 2017 p.

Висновки. Найбільш чутливими до викидів шкідливих речовин та $\mathrm{CO}_{2}$ в атмосферу виявилися показники первинної захворюваності на хвороби сечостатевої системи, нервової системи, системи кровообігу та уроджені аномалії. Найбільш негативний вплив на значення показників усіх класів первинної захворюваності на Харківщині чинять $\mathrm{CO}_{2}, \mathrm{~N}_{2} \mathrm{O}$.

КЛЮЧОВІ СЛОВА: екологічні чинники, первинна захворюваність, Харківська область, динаміка захворюваності, викиди, забруднюючі речовини

Некос А. Н. ${ }^{1}$, Муромцева Ю. І. ${ }^{2}$

${ }^{1}$ Харьковский наииональный университет имени В. Н. Каразина, площадь Свободы, 6, г. Харьков, 61022, Украина

${ }^{2}$ Харьковский национальный педагогический университет имени Г.С. Сковороды, ул. Алчевских, 29 , г.. Харьков, 61002, Украина

ОЦЕНКА ВЛИЯНИЯ ВЫБРОСОВ ЗАГРЯЗНЯЮЩИХ ВЕЩЕСТВ В АТМОСФЕРУ НА ПОКАЗАТЕЛИ ПЕРВИЧНОЙ ЗАБОЛЕВАНИЯ НАСЕЛЕНИЯ (НА ПРИМЕРЕ ХАРЬКОВСКОЙ ОБЛАСТИ)

Цель. Установить структурные сдвиги в показателях первичной заболеваемости населения, и определить взаимосвязь между показателями выбросов загрязняющих веществ в атмосферный воздух и первичной заболеваемостью населения Харьковской области.

Методы. Системный подход, статистические методы.

Результаты. Рассмотрены структура и динамика количества впервые зарегистрированных случаев заболеваний и первичной заболеваемости населения за период с 2004 по 2017 гг. Проведен корреляционно-регрессионный анализ связей между объемами выбросов и первичной заболеваемостью по классам болезней в Харьковской области, который показал наличие заметной связи между явлениями. Синтезированные уравнения регрессии можно использовать для определения влияния каждого отдельного фактора (выброс $\mathrm{SO}_{2}, \mathrm{CO}_{2}, \mathrm{~N}_{2} \mathrm{O}$ ) на первичную заболеваемость населения по различным классам болезней. В структуре первичной заболеваемости населения Харьковской области значительную долю занимают болезни органов дыхания, системы кровообращения и нервной системы - их удельный вес увеличился с 49\% в 2004 гг. до $51 \%$ в 2017

Выводы. Наиболее чувствительными к выбросам вредных веществ и $\mathrm{CO}_{2}$ в атмосферу оказались показатели первичной заболеваемости болезнями мочеполовой системы, нервной системы, системы кровообращения и врожденные аномалии. Наиболее негативное влияние на значения показателей всех классов первичной заболеваемости в Харьковской области оказывают $\mathrm{CO}_{2}, \mathrm{~N}_{2} \mathrm{O}$.

КЛЮЧЕВЫЕ СЛОВА: экологические факторы, первичная заболеваемость, Харьковская область, динамика заболеваемости, выбросы, загрязняющие вещества

\section{Introduction}

Healthy human life in a nature friendly environment is an indisputable privilege and a global goal of sustainable human development. For a long time, Ukraine has been dominated by resource- and energy-intensive industries and technologies, raw material-oriented exports, excessive concentration of production in industrial regions, which is counter-productive for environment friendly living. The level of socio-economic development, welfare and health of the population does not correspond to the natural, scientific and technical, production potential of Ukraine. In addition, Ukraine has international obligations to ensure the goals of sustainable development, defined by UN strategic documents and enshrined in the Order of the
President of Ukraine on the Sustainable Development Goals of Ukraine until 2030 [1].

Thus, the analysis and monitoring of factors influencing the implementation of sustainable development goals in Ukraine, namely ensuring a healthy lifestyle and promoting wellbeing for all at any age, ensuring openness, security, sustainability and environmental sustainability of cities and other settlements, is important. The dynamics of morbidity in the Kharkiv region due to the influence of anthropogenic factors have not been studied well. The analysis of trends in the incidence and prevalence of diseases among the population is an important component of planning strategic areas of social development of the region, medical 
care, scientific basis for developing an effective system for preserving and promoting public health. Therefore, the study of factors influencing the primary morbidity of the population at the present stage is important for such an economically powerful region of Ukraine as Kharkiv region.

Research into the problems of morbidity and health of the population is of interest to not only medical scientists, but also to geographers, demographers, ecologists, and economists. The issues relating to regional population morbidity and factors contributing to this were covered in the works of Ukrainian scientists - Mezentseva N.I., Batychenko S.P., Mezentseva K.V.[2], Krainyukova O.M., Yakusheva A.V.[3], Shevchuk L.T., Gutsulyak V.M. [4], Baranovsky V.A., Pirozhenko K.G., Shevchenko V.O., Kornus O.G., Kornus A.O., [5], Shishchuk V.D., Volosovets O.P., Krivopustov S.P. [6], Kryuchko T.O., Honchar M.O., Abaturov O.E., Bolbot Yu.K., Kuzmenko A.Ya., Loginova I.O., Squarska O.O., Iordanova S.V. and other. The impact of environmental factors on public health was considered in the works of Voitko O.V., Omelchuk C.T., Ostapchuk Yu.M. [7], Nekos, A.N.; Medvedeva, Yu.V. [8],
Tsyganenko O.I., Khomenko I.M., Persheguba J.V. [9] and others.

Demographic situation in Ukraine began to be characterized as a crisis in the late 80 's of the twentieth century [10]. This was due to negative natural population growth due to declining birth rates and increasing death rates, declining life expectancy, an aging nation, and migratory outflows. At that time and later, most economists and demographers associated Ukraine's lag from developed countries in terms of life expectancy and mortality rates with the socio-economic crisis in society, a difficult transition to market relations [11]. However, these are not the main reasons influencing demographic processes. Population mortality is also naturally and ecologically conditioned as repeatedly stated in the reports of the World Health Organization [12], and directly depends on the morbidity of the population [13].

The aim of this study is to establish structural changes in the indicators of primary morbidity of the population. We also aim to determine the relationship between the indicators of emissions of pollutants into the atmosphere and the primary morbidity of the population of Kharkiv region.

\section{Materials and methods}

The study is based on the analysis of published statistical data of the Main Department of Statistics in Kharkiv region, the State Statistics Service of Ukraine. For the study we used general scientific methods - a systematic approach, analysis and synthesis, statistical methods (grouping, graphics, correlation and regression analysis, time series etc.). For the study environmental and medical-demographic phenomena for processing statistical materials was used Microsoft EXCEL software package. Calculations of multiple regression were performed using
Microsoft EXCEL (Analysis ToolPak -> Regression).

The period from 2004 to 2017 was chosen for the study, which covers all the necessary medical, demographic and environmental indicators. The structure and dynamics of the number of first registered cases of diseases were considered, and the indicator of primary morbidity of the population was calculated as the ratio of the number of first registered cases of diseases among the population per year to the average annual number of available population.

\section{Results}

During the period from 2004 to 2017, the number of newly registered cases of the disease among the population decreased from 2326.3 to 1777.2 thousand people (by $23.6 \%$ ). The decrease in cases of newly registered diseases occurred not only in absolute terms (549.1 thousand people) but also in relative terms - from 811 persons/1000 populations to 658 persons/1000 population, or by $18.9 \%$ (Fig. 1). The annual average rate of decline in primary morbidity over the 14-year period from 2004 to 2017 was $1.6 \%$.

In the structure of morbidity, which is registered for the first time, the major share is occupied by respiratory diseases, their share increased from $35 \%$ in 2004 to $40 \%$ in 2017 (Fig. 1). 
Diseases of the circulatory system make a significant contribution to morbidity. On the positive side, their share decreased from $11 \%$ in 2004 to $8 \%$ in 2017 . The proportion of other diseases (neoplasms, diseases of the nervous and urogenital systems, skin and subcutaneous tissue diseases, diseases of the musculoskeletal system and connective tissue, congenital anomalies) remained in 2017 at the same level as in 2004. A significant proportion of first-time cases are related to "other causes" - 25\% in 2004 and $24 \%$ in 2017.

During the same period (2004-2017) the quantitative indicators and chemical composition of pollutant emissions into the atmosphere in the Kharkiv region were analyzed. Information on emissions of pollutants into the atmosphere is provided by the State Statistics Service of Ukraine in accordance with the Methodological Regulations [14]:

- greenhouse gas emissions $\left(\mathrm{N}_{2} \mathrm{O}, \mathrm{CH}_{4}\right.$, HFCs, PFCs, $\mathrm{SF}_{6}$ );

- emissions of pollutants (NOx, CO, NMVOC, $\mathrm{NH}_{3}$ );

- emissions of solid suspended particles (less than $10 \mu \mathrm{m}$ and $2.5 \mu \mathrm{m}$ ).

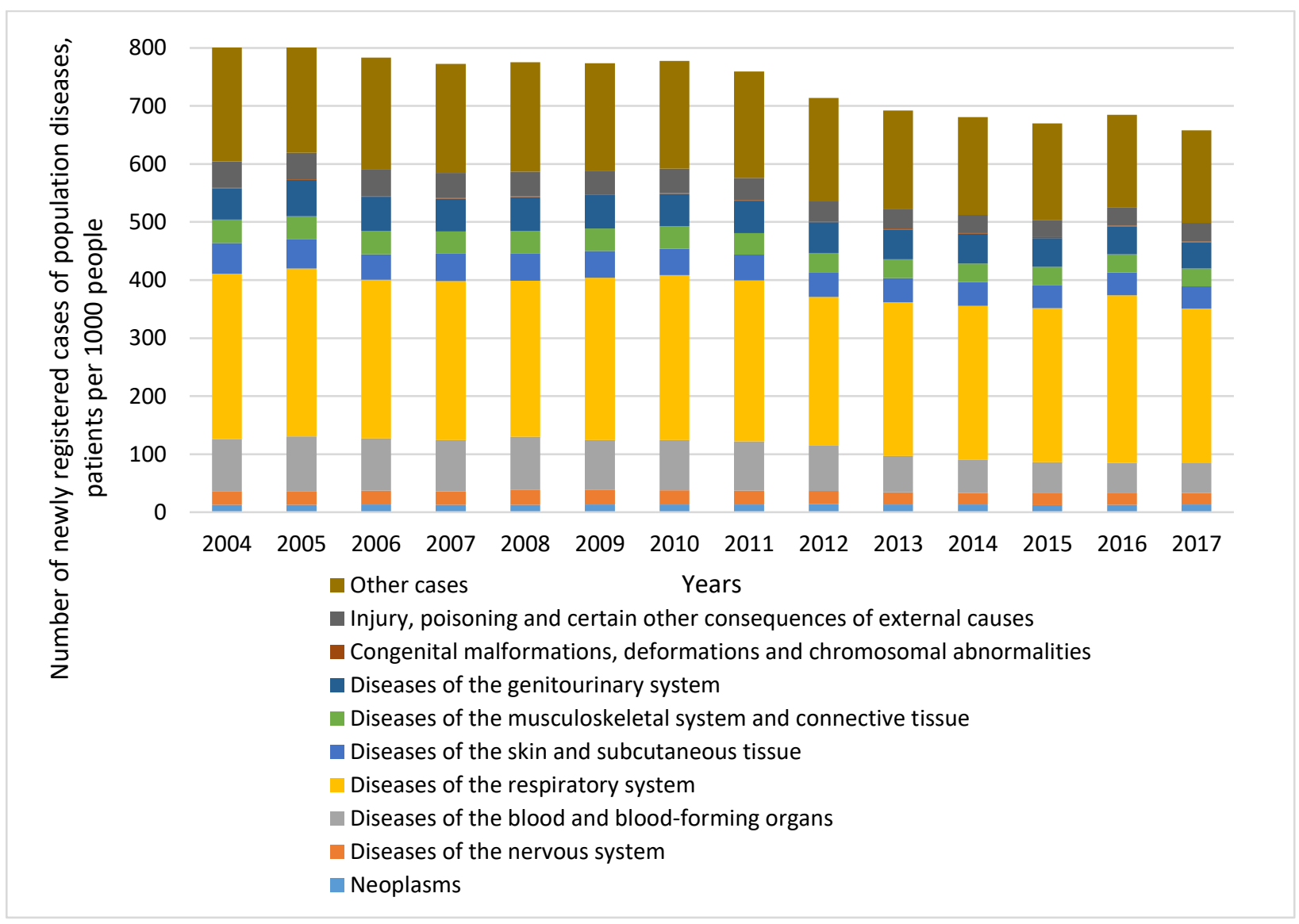

Fig. 1 - Dynamics of first registered cases of diseases of the population of Kharkiv region in 2004 - 2017 , per 1000 people (http://kh.ukrstat.gov.ua/index.php/zakhvoriuvanist-naselennia )

During the study, the total impact on the incidence of all these emissions into the atmosphere was analyzed, as well as the impact of individual substances - sulfur dioxide, nitrogen dioxide, carbon dioxide. The above compounds cause harmful effects on the human body in concentrations above the maximum allowable (MPC). According to the authors [5] - "Dust causes allergic diseases, pneumonia, bronchial asthma, infectious diseases, cardiovascular diseases, malignant neoplasms. Carbon monoxide is the cause of oxygen starvation, fatal lesions, the development of inflammatory processes in the respiratory tract and lung tissue, tachycardia, arrhythmia, increased blood pressure, increased stroke and cardiac output, suppression of vascular tone, erythrocytosis, hyperglycemia and glucose acidosis, detoxification of the liver 
and kidneys. Mild poisoning is manifested by general malaise, headache. Severe poisoning develops coma, and later - nervous disorders in the form of paralysis, paresis, memory loss, inability to prolong mental stress. Silicon dioxide - gives severe lung disease. Nitrogen oxide pulmonary edema, disorders of vitamin metabolism. Hydrocarbons - headache, dizziness. Sulfur oxide - pulmonary edema, pharynx and respiratory paralysis, severe nervous disorders, mental disorders, Yokkait asthma.

In Fig. 2 shows emissions of pollutants (greenhouse gases, $\mathrm{NOx}, \mathrm{CO}, \mathrm{NMVOC}, \mathrm{NH}_{3}$, emissions of solid suspended particles less than $10 \mu \mathrm{m}$ and $2.5 \mu \mathrm{m})$ per 1 person $(\mathrm{kg} /$ person $)$ and separately - carbon dioxide (t/person). As you can see, there was a reduction in all pollutant emissions from $102.9 \mathrm{~kg} /$ person to $16.7 \mathrm{~kg} /$ person, i.e. more than 6 times, and carbon dioxide emissions from $3.87 \mathrm{t} /$ person to $2.15 \mathrm{t} /$ person, i.e. decreased by 1.8 times. The most noticeable reduction in emissions of all pollutants occurred in the period from 2014 to 2017 , while from 2004 to 2013 the emissions into the atmosphere remained at an average of $108.3 \mathrm{~kg} /$ person of pollutants and $4.4 \mathrm{t} /$ person of carbon dioxide.

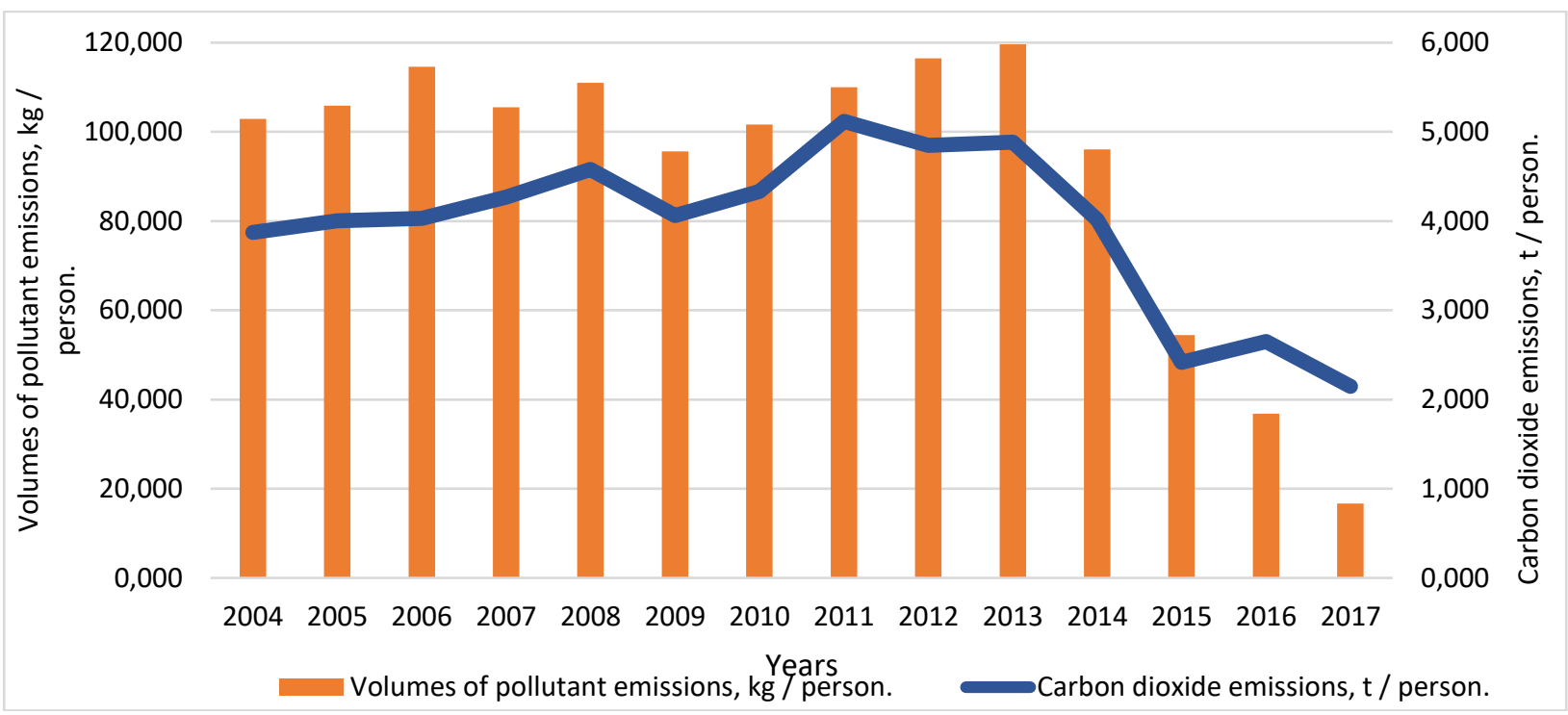

Fig. 2 - Volumes of pollutant emissions into the atmosphere and carbon dioxide per capita for 2004 - 2017 in Kharkiv region

(http://kh.ukrstat.gov.ua/navkolyshnie-seredovyshche-stat/1058-vykydy/1478-vykydy-dioksydu-sirkyta-oksydiv-azotu-v-atmosferne-povitria-1990-2014-rr and http://kh.ukrstat.gov.ua/dynamika-vykydiv-zabrudniuiuchykh-rechovyn-i-dioksydu-vuhletsiu-v-atmosferne-povitria)

J. Robbins found that human health depends on the environmental situation [5, p.29], so the next stage of the study was a correlationregression analysis of the relationship between emissions per capita and primary morbidity by disease classes in Kharkiv region for the period 2004 - 2017. The results of calculations of correlation coefficients are presented in Table 1.

Thus, the most dependent on the environmental situation in the Kharkiv region were the incidence of diseases of the genitourinary system, nervous system, circulatory system - as evidenced by correlation coefficients with values greater than 0.6 , which corresponds to a moderate relationship on the Cheddock scale. Incidence rates of congenital anomalies were inversely related to the amount of emissions into the atmosphere. Thus, the primary morbidity of diseases of the nervous system decreased since 2004 from 22.7 cases/1000 people to 20.3 (by $10.6 \%$ ), diseases of the circulatory system from 90.5 to 50.9 per 1000 people (in 1,78 times), diseases of the genitourinary system from 53.8 to 45.0 per 1000 people (16.4\%), and congenital anomalies increased from 1.6 times - from 1.0 to 1.6 per 1000 people. Nitrogen dioxide and carbon dioxide have the greatest impact on all types of diseases in the Kharkiv region.

To construct multiple regression on the basis of the data in Table 1, classes of diseases and pollutants were selected, the correlation coefficient between which was more than 0.5 . Thus, multifactor models of linear relationship between the studied phenomena were synthesized, which are presented in Table 2. 


\section{Correlation coefficients between emissions of substances into the atmosphere and primary morbidity of the population of Kharkiv region}

\begin{tabular}{|c|c|c|c|c|c|c|c|c|c|}
\hline \multirow[b]{2}{*}{ 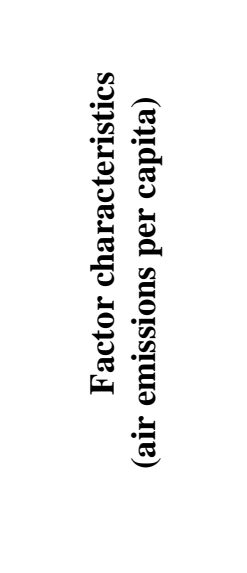 } & \multicolumn{9}{|c|}{$\begin{array}{l}\text { Dependent variable (number of first registered cases of diseases, } \\
\text { Per } 1000 \text { people) }\end{array}$} \\
\hline & 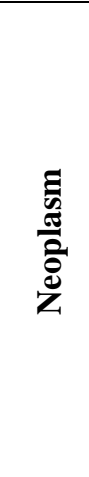 & 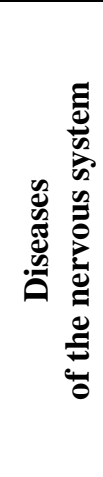 & 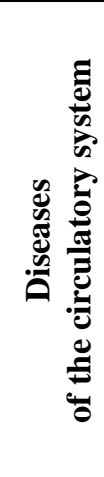 & 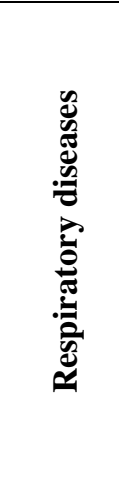 & 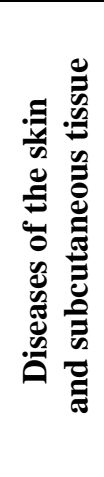 & 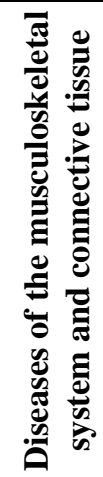 & 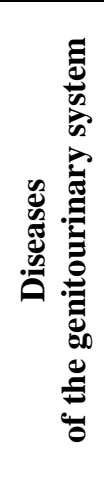 & 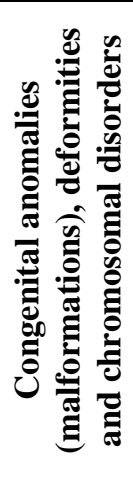 & 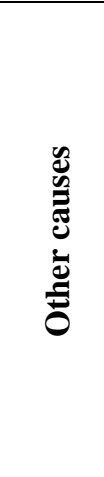 \\
\hline Sulfur dioxide & 0,626 & 0,369 & 0,381 & $-0,234$ & 0,159 & 0,230 & 0,428 & $-0,305$ & 0,254 \\
\hline Nitrogen dioxide & 0,195 & 0,617 & 0,651 & $-0,159$ & 0,517 & 0,525 & 0,687 & $-0,569$ & 0,583 \\
\hline Carbon dioxide & 0,488 & 0,621 & 0,637 & $-0,099$ & 0,434 & 0,487 & 0,627 & $-0,536$ & 0,515 \\
\hline $\begin{array}{l}\text { All emissions } \\
\text { except } \mathrm{CO}_{2}\end{array}$ & 0,344 & $-0,108$ & $-0,257$ & $-0,012$ & $-0,216$ & $-0,262$ & $-0,527$ & 0,176 & $-0,202$ \\
\hline
\end{tabular}

Dependence of primary morbidity of the population of Kharkiv region on volumes of $\mathrm{SO}_{2}, \mathrm{CO}_{2}, \mathrm{~N}_{2} \mathrm{O}$ emissions into the atmosphere per 1 person (2004 - 2017)

\begin{tabular}{|l|l|c|}
\hline \multicolumn{1}{|c|}{ Classes of diseases } & \multicolumn{1}{c|}{ Equation of dependence } & R-square \\
\hline Diseases of the circulatory system & $\mathrm{y}=1,87+1,72 \mathrm{X}_{1}+26,8 \mathrm{X}_{2}+1,19 \mathrm{X}_{3}$ & 0,65 \\
\hline Diseases of the genitourinary system & $\mathrm{y}=37,3-0,31 \mathrm{X}_{1}+3,83 \mathrm{X}_{2}+\mathrm{X}_{3}$ & 0,56 \\
\hline Diseases of the nervous system & $\mathrm{y}=14-0,2 \mathrm{X}_{1}+3,31 \mathrm{X}_{2}+0,05 \mathrm{X}_{3}$ & 0,61 \\
\hline Congenital anomalies & $\mathrm{y}=2,1+0,02 \mathrm{X}_{1}-0,27 \mathrm{X}_{2}-0,02 \mathrm{X}_{3}$ & 0,51 \\
\hline
\end{tabular}

General view model

$$
y=a_{0}+a_{1} X_{1}+a_{2} X_{2}+a_{3} X_{3},
$$

where $\mathrm{Y}-$ is the corresponding level of primary morbidity;

$\mathrm{X}_{1}$ - sulfur dioxide emissions;

$\mathrm{X}_{2}-$ carbon dioxide emissions;

$\mathrm{X}_{3}$ - emissions of nitrogen dioxide;

$\mathrm{a}_{1}, \mathrm{a}_{2}, \mathrm{a}_{3}$ - regression coefficients;

$\mathrm{a}_{0}$ - baseline morbidity, i.e. without taking into account the impact of emissions into the atmosphere.
Based on the synthesized equations, we can simulate the situation and calculate the forecast in the absence of pollutants emissions into the atmosphere, ie at $X_{1}=X_{2}=X_{3}=0$, or at other values (reduced or increased) of these emissions into the air. This will allow predicting the probable levels of additional primary morbidity (in case of deterioration of the environmental situation) or an increase in the number of healthy people (subject to further reduction of pollutants emissions into the atmosphere).

\section{Discussion}

Important in the territorial-nosological analysis is the assessment of the relationship between the quantitative and qualitative composition of environmental pollution and the structure of morbidity. Such a study was conducted at the regional level for the Kharkiv region. 
As you can see, most of the consequences of poisoning are diseases of the respiratory, nervous and cardiovascular systems of the human body. And these 3 classes of diseases make up the vast majority of cases of primary morbidity in the Kharkiv region, the share of which increased from $49 \%$ in 2004 to $51 \%$ in 2017.

For the group "other causes" of the morbidity, the correlation coefficients, according to the Chaddock scale, indicate a moderate relationship between air emissions per capita. The group of "other cases of diseases" according to the International Statistical Classification of Diseases and Related Health Problems (ICD10) includes the following diseases - some infectious and parasitic diseases; diseases of the blood and blood-forming organs and certain disorders involving the immune mechanism; diseases of the endocrine system, eating disorders and metabolic disorders; mental and behavioral disorders; diseases of the eye and appendages; diseases of the ear and papilla; diseases of the digestive system; pregnancy, childbirth and the postpartum period; certain conditions that occur in the perinatal period; symptoms, signs and abnormalities found in laboratory and clinical studies, not classified in other headings and external causes of morbidity and mortality. However, this group in terms of disease genesis is the most heterogeneous compared to other disease groups, so it requires a separate study.

Regarding the groups of primary morbidity, which showed a weak dependence on pollutant emissions into the atmosphere $(\mathrm{r}<0.5)$ - respiratory diseases, skin and subcutaneous tissue diseases, diseases of the musculoskeletal system and connective tissue, they also require further study. Recent researches by Sasha Khomenko, MSc Marta Cirach and others [15], Jerrett, M., Burnett, R. T. and others [16] have shown that air emissions affect morbidity and mortality, especially in urban areas, such as large European and American cities. Also, the authors of Kenneth Y. Chay, Michael Greenstone [17], found that air pollution has the greatest impact on infant mortality.

Thus, air pollution has a detrimental effect on our lives in many ways. Therefore, further studies of the impact of air emissions on the primary morbidity of the population should be conducted - place of residence - rural areas or urban geosystem, sex-age cohorts, as well as indicators of professionally oriented groups (industrial workers (including in terms of occupational diseases), office workers and those who work outdoors). In addition, primary morbidity rates should be analyzed in conjunction with relevant mortality rates.

\section{Conclusions}

During the period from 2004 to 2017 in the Kharkiv region there has been a decrease in the number of emissions of pollutants into the atmosphere, which coincides with a decrease in the number of cases of newly registered morbidity of the population of the region. Primary morbidity rates decreased in 2017 compared to 2004 by $18.9 \%$, while emissions were reduced by 6 times and carbon dioxide emissions by 1.8 times (a significant reduction in emissions occurred after 2014, which can be explained with changes in foreign policy and socio-economic changes in the country and the region as a whole).

Primary morbidity is the result of endogenous and exogenous causes, and the performed correlation-regression analysis of the impact of pollutant emissions into the atmosphere on the primary morbidity of the population showed only a moderate relation between them. The most sensitive to emissions of pollutants and carbon dioxide into the atmosphere were the indicators of primary incidence of diseases of the genitourinary system, nervous system, circulatory system and congenital anomalies. Nitrogen dioxide and carbon dioxide have the most negative impact on the values of indicators of all classes of primary morbidity in Kharkiv region.

Carried out correlation-regression analysis and modeling of primary morbidity depending on the indicators of pollutants emissions into the atmosphere is of practical importance. Thus, it is possible to determine the impact of each individual factor (emissions of nitrogen dioxide, sulfur dioxide and carbon dioxide) on the primary morbidity of the population for different classes of diseases. 


\section{Conflict of interest}

The authors state that there is no conflict of interest in the publication of this manuscript. In addition, the authors fully adhered to ethical standards, including plagiarism, data falsification, and double publication.

\section{References}

1. Decree of the President of Ukraine on the Sustainable Development Goals of Ukraine for the period up to 2030 of September 30, 2019 № 722/2019. (2019). Retrieved from https://zakon.rada.gov.ua/laws/show/722/2019\#Text (In Ukrainian)

2. Mezentseva, N. I., Batichenko, S. P. \& Mezentsev, K. V. (2018). Morbidity and health of the population in Ukraine: socio-geographical dimension: a monograph. Kyiv: State Enterprise "Print Service". (In Ukrainian)

3. Krainyukov, O. M. \& Yakusheva, A.V. (2016). Assessment of risk to human health due to the use of oilcontaminated drinking water using RAIS (US-EPA). Man and the environment. Issues of neoecology, (3-4 (26), 46-51. Retrieved from https://periodicals.karazin.ua/humanenviron/article/view/7752 (In Ukrainian)

4. Gutsulyak, V. M. \& Nakonechny, K.P. (2010). Medico-ecological assessment of landscapes of Chernivtsi region: Monograph. Chernivtsi: Ruta. (In Ukrainian)

5. Kornus, O. G., Kornus, A. O. \& Shishchuk, V. D. (2015). Territorial and nosological structure of morbidity of the population of Sumy region: monograph. Sumy State Pedagogical University named after A.S. Makarenko; Sumy State University, Medical Institute. Sumy: Sumy State Pedagogical University named after A.S. Makarenko,. 172 p. (In Ukrainian)

6. Volosovets, O. P., Kryvopusrov, S. P., Kruchko etc (2018). The impact of environmentally unfavorable environment on the incidence and prevalence of diseases of the circulatory system in children of Ukraine. Public health. Health of Society, T. 7 (№ 5). pp. 229-236. https://doi.org/10.22141/2306-2436.7.5.2018.158608 (In Ukrainian)

7. Voitko, O. V., Omelchuk, S. T. \& Ostapchuk Yu. M. (2009). Influence of certain anthropogenic factors on the incidence of lung cancer in the population of Ukraine. Oncology,11(4), 257-262. (In Ukrainian)

8. Nekos, A. N. \& Medvedeva, Yu. V. (2018). Ecological safety of food plant products grown in the conditions of technogenic-transformed landscapes of the urban geosystem. Proceedings of VI International. scientific Conference (on the 110th anniversary of the birth of Professor V.A. Dementiev):Modern problems of landscape science and geoecology, Minsk, 2018, November 13-16 ( pp. 148-151). Minsk: BSU. (In Russian)

9. Tsyganenko, O. I., Khomenko, I. M., Persheguba, Ya. V., Sklyarova, N. A. \& Avramenko, L. M. (2018). Influence on ecological health of athletes of cold atmospheric air. Man and the environment. Issues of neoecology, (30), 158-165. https://doi.org/10.26565/1992-4224-2018-30-14 (In Ukrainian)

10. Kulchytsky, S.V. (2007). Demographic losses of Ukraine // Encyclopedia of Modern Ukraine: electronic version [website] / ch. editor: I.M. Dziuba, AI Zhukovsky, MG Zheleznyak and others; NAS of Ukraine, NTSh. Kyiv: Institute of Encyclopedic Research of the National Academy of Sciences of Ukraine, 2007. Retrieved from http://esu.com.ua/search articles.php?id=21468 (In Ukrainian)

11. Muromtseva, Yu. I. (2015). The role of culturological factors in overcoming the demographic crisis in Ukraine. Language. Science. Culture: Proceedings of the interdisciplinary scientific-practical conference dedicated to the 85th anniversary of the Petro Vasylenko, Kharkiv, 2015, June 10, (pp. 793-803). Kharkiv National Technical University of Agriculture. (In Ukrainian)

12. WHO Air quality guidelines for particulate matter, ozone, nitrogen dioxide and sulfur dioxide. (2006). Retrieved from https://www.who.int/phe/health topics/outdoorair/outdoorair aqg/en/

13. Brown, Tim. (2010). A Companion to Health and Medical Geography. Wiley-Blackwell.

14. Methodological provisions for the calculation of emissions into the atmosphere. Retrieved from http://www.ukrstat.gov.ua/norm doc/2020/268/268.pdf (In Ukrainian)

15. Khomenko, Sasha, Cirach, Marta, Pereira-Barboza, Evelise, Mueller, Natalie, Barrera-Gómez, Jose, RojasRueda, David...\& Nieuwenhuijsen, Mark. (2021). Premature mortality due to air pollution in European cities: a health impact assessment The Lancet. Planetary Health, 5 (3), E121-E134. https://doi.org/10.1016/S2542-5196(20)30272-2

16. Jerrett, M., Burnett, R. T., Beckerman, B. S., Turner, M. C., Krewski, D. \& Thurston, G. (2013). Spatial analysis of air pollution and mortality in California. American journal of respiratory and critical care medicine, 188(5), 593-599. https://doi.org/10.1164/rccm.201303-0609OC

17. Chay, Kenneth Y. \& Greenstone, Michael. (2003). The Impact of Air Pollution on Infant Mortality: Evidence from Geographic Variation in Pollution Shocks Induced by a Recession. The Quarterly Journal of Economics, 118 (3), 1121-1167. https://doi.org/10.1162/00335530360698513 


\section{Література}

1. Указ Президента України Про Цілі сталого розвитку України на період до 2030 року від 30 вересня 2019 року № 722/2019. URL: https://zakon.rada.gov.ua/laws/show/722/2019\#Text

2. Мезенцева Н.І., Батиченко С.П., Мезенцев К.В. Захворюваність і здоров'я населення в Україні: суспільно-географічний вимір: монографія. - К.: ДП «Прінт Сервіс», 2018. - 136 с.

3. Крайнюков О.М., Якушева А. В. Оцінка ризику для здоров'я людей, обумовленого використанням забруднених нафтопродуктами питних вод за допомогою методики RAIS (US-EPA). Людина та довкілля. Проблеми неоекологіï. № 3-4 (26), 2016. C. 46-51. URL: https://periodicals.karazin.ua/humanenviron/article/view/7752

4. Гуцуляк В. М., Наконечний К. П. Медико-екологічна оцінка ландшафтів Чернівецької області: Монографія. Чернівці: Рута, 2010. 150 с.

5. Корнус О. Г., Корнус А. О., Шищук В. Д. Територіально-нозологічна структура захворюваності населення Сумської області: монографія. Суми: СумДПУ імені А.С. Макаренка, 2015. 172 с.

6. Волосовець О.П. Кривопустов С.П. Крючко Т. О., та ін.. Вплив екологічно несприятливого довкілля на захворюваність та поширеність хвороб системи кровообігу у дітей України. Здоров'я суспільства. Здоровье общества. Health of Society. 2018. T. 7. № 5. C. 229-236. DOI: https://doi.org/10.22141/23062436.7.5.2018.158608

7. Войтко О.В., Омельчук С.Т., Остапчук Ю.М. Вплив окремих антропогенних факторів на захворюваність населення України на рак легенів. Онкологія. 2009. Т.11, № 4. С. 257-262.

8. Некос А.Н., Медведева Ю.В. Экологическая безопасность пищевой растительной продукции, выращенной в условиях техногенно-преобразованных ландшафтов урбогеосистемы. Современные проблемы ландмафтоведения и геоэкологии: материаль VI Междунар. науч. конф.(к 110-летию со дня рождения профессора В.А. Дементьева), Минск, 13-16 нояб. 2018 г.-Минск: БГУ, 2018. С. 148-151.

9. Циганенко О. І., Хоменко І. М., Першегуба Я. В., Склярова Н. А., Авраменко Л. М. Вплив на екологічне здоров'я спортсменів холодного атмосферного повітря. Людина та довкілля. Проблеми неоекологіï. 2018. Вип. 30. С. 158-165. DOI: https://doi.org/10.26565/1992-4224-2018-30-14

10. Кульчицький С. В. Демографічні втрати України. Енциклопедія Сучасної України. Київ: Інститут енциклопедичних досліджень НАН України, 2007. URL: http://esu.com.ua/search articles.php?id=21468

11. Муромцева Ю. І. Роль культурологічних чинників у подоланні демографічної кризи в України. Мова. Наука. Культура: матеріали міждисиипл. наук.-практ. конф., присвяченої 85-річчю Харківського наиіонального технічного університету сільського господарства імені Петра Василенка, Харків, 10 черв. 2015. C. 793-803

12. WHO Air quality guidelines for particulate matter, ozone, nitrogen dioxide and sulfur dioxide. 2006. URL: https://www.who.int/phe/health_topics/outdoorair/outdoorair_aqg/en/

13. Tim Brown. A Companion to Health and Medical Geography. Wiley-Blackwell, 2010. $640 \mathrm{p}$.

14. Методологічні положення зі складання рахунку викидів у атмосферне повітря. URL: http://www.ukrstat.gov.ua/norm_doc/2020/268/268.pdf

15. Khomenko Sasha, Cirach Marta, Pereira-Barboza Evelise, Mueller Natalie, Barrera-Gómez Jose, RojasRueda David, Koes de Hoogh, Hoek Gerard, Nieuwenhuijsen Mark. Premature mortality due to air pollution in European cities: a health impact assessment. The Lancet Planetary Health. 2021. Vol. 5. No 3. P. E121E134. DOI: https://doi.org/10.1016/S2542-5196(20)30272-2

16. Jerrett, M., Burnett, R. T., Beckerman, B. S., Turner, M. C., Krewski, D., Thurston, G., ... \& Pope III, C. A. Spatial analysis of air pollution and mortality in California. American journal of respiratory and critical care medicine. 2013. Vol. 188. No 5. P. 593-599. DOI: https://doi.org/10.1164/rccm.201303-0609OC

17. Kenneth Y. Chay, Michael Greenstone. The Impact of Air Pollution on Infant Mortality: Evidence from Geographic Variation in Pollution Shocks Induced by a Recession. The Quarterly Journal of Economics. 2003. Vol. 118. Issue 3. P. 1121-1167. DOI: https://doi.org/10.1162/00335530360698513 